\title{
TERMINUS RESPONSE OF LEWIS GLACIER, MOUNT KENYA, KENYA, TO SINUSOIDAL NET-BALANCE FORCING†
}

\author{
By Phillip Kruss* \\ (Department of Meteorology, University of Wisconsin-Madison, 1225 West Dayton Street, Madison, Wisconsin 53706, U.S.A.)
}

\begin{abstract}
Climatic change occurs over a wide range of time scales. Each glacier responds in a unique fashion to this spectrum of climatic forcings. The response of the extent of the Lewis Glacier terminus to sinusoidal fluctuation in the net balance is calculated. The net balance versus elevation profile is separately translated along the orthogonal balance and elevation axes. Net balance amplitudes of 0.1 to $0.5 \mathrm{~m} \mathrm{a}^{-1}$ of ice and 10 to $50 \mathrm{~m}$ elevation, respectively, and periods ranging from 20 to 1000 years are covered. The time lag between forcing and terminus response is dependent on applied period, reaching a maximum of about 30 years at 1000 years period, but is independent of applied amplitude. For the shorter applied periods the response amplitude increases rapidly with period but asymptotically approaches a maximum at periods above approximately 200 years; it is linearly dependent on applied amplitude. Consideration of the Lewis Glacier response taken in perspective with similar results for other alpine glaciers identifies general characteristics of the terminus response.
\end{abstract}

RÉsumé. La réponse de la langue terminale du Lewis Glacier, Mount Kenya, Kenya, $\dot{a}$ des oscillations sinusoidals du bilan de masse. Les fluctuations climatiques se produisent suivant des échelles de temps très différentes. On a calculé la réponse de la langue terminale du Lewis Glacier à une fluctuation sinusoïdale du bilan de masse. Le profil des bilans en fonction de l'altitude est transcrit séparément suivant des axes orthogonaux bilan/altitude. On a couvert des amplitudes de bilans de 0,1 à $0,5 \mathrm{~m} \mathrm{a}^{-1}$ de glace et d'altitudes de 10 à $50 \mathrm{~m}$ respectivement sur des périodes allant de 20 à 1000 ans. Le temps de réponse entre l'incitation du bilan et le mouvement de la langue dépend de la période choisis, il atteint un maximum d'environ 30 ans pour des périodes de 1000 ans mais il est indépendant de l'amplitude. Pour les periodes plus courtes l'amplitude de la réponse augmente rapidement avec

\section{INTRODUCTION}

Lewis Glacier on Mount Kenya (lat. $0^{\circ} 09^{\prime} \mathrm{S}$., long. $37^{\circ} 19^{\prime} \mathrm{E}$.) is the subject of a climate-monitoring program in which both recent climatic change in East Africa and the interaction between climate and glacier are being studied (Hastenrath, 1975; Caukwell and Hastenrath, 1977; Hastenrath and Caukwe11, 1979; Hastenrath and Kruss, [1981], 1982; Bhatt and others, [1982]; Kruss, in press). For the most important earlier work on Lewis Glacier the reader should refer to Troll and Wien (1949) and Charnley (1959). Of considerable interest in the context of the present project is the response of Lewis Glacier to given climatic forcings, an effect which is dependent on the time scale and magnitude of the climatic event as well as on the physical characteristics of the glacier itself. In view of the link between climate, net balance, and the glacier, general characteristics can be investigated by examining net balance variation. A calculation is made of the response of the extent of the Lewis Glacier terminus to repeated sinusoidal netbalance oscillations of various periods and amplitudes.

The technique used involves first the modeling of a steady-state glacier of a certain length. This is accomplished by translating the vertical netbalance profile by the amount necessary to produce the required length. Sinusoidal perturbations are then applied about the displaced net balance and the terminus response is monitored.

For Lewis Glacier, two separate steady states of

*Present address: Institute of Polar Studies, The Ohio State University, 125 South Oval Mall, Columbus, Ohio 43210, U.S.A.

†Contribution No. 510, Institute of Polar Studies, Ohio State University. la période mais se rapproche asymptotiquement du maximum pour des périodes de l'ordre de $200 \mathrm{ans}$; elle est linéairement liée à l'amplitude de l'incitation. La prise en compte de la réponse du Lewis Glacier en comparaison avec des résultats analogues pour d'autres glaciers alpins permet de caractériser les traits généraux de la réponse des langues.

Zusammenfassung. Ansprechen des Zungenendes des Lewis Glacier, Mount Kenya, Kenya, auf sinusformige Schwankungen der Massenbilanz. Klimaänderungen ereignen sich über einen weiten Bereich von Zeitskalen. Jeder Gletscher spricht auf dieses Spektrum von Klimageschehnissen in ihm eigener Weise an. Es wird hier das Ansprechen des Zungenendes des Lewis Glacier auf sinusformige Schwankungen in der Massenbilanz berechnet. Das Vertikalprofil der Massenbilanz wird getrennt längs der zueinander senkrechten Bilanz- und Höhenachsen verschoben. Dabei werder Amplituden der Massenbilanz von 0,1 bis $0,5 \mathrm{~m} \mathrm{a}^{-1}$ und Amplituden der Höhe von 10 bis $50 \mathrm{~m}$ behandelt, sowie Perioden von 20 bis 1000 Jahren. Der Phasenunterschied zwischen dem Klimaereignis und dem Ansprechen des Zungenendes hängt von der Periode des Klimageschehens ab, derart, dass ein Maximum von etwa 30 Jahren bei einer Periode von 1000 Jahren erreicht wird; dagegen ist der Phasenunterschied unabhängig von der Amplitude des Klimageschehens. Für die kürzeren Perioden des Klimageschehens nimmt die Amplitude des Ansprechens der Gletscherzunge rasch mit zunehmender Periode zu, aber sie erreicht ein Maximum bei Perioden oberhalb etwa 200 Jahren; das Ansprechen der Gletscherzunge hängt linear von der Amplitude des Klimageschehens ab. In Zusammenhang mit ähnlichen Ergebnissen für andere Gletscher zeigen die Betrachtungen für den Lewis Glacier allgemeine Charakteristiken des Ansprechens der Gletscherzunge auf.

the correct length are computed; one by translating the curve of net balance versus elevation with respect to the balance axis; the other by moving this curve along the orthogonal elevation axis. The former translation is essentially a precipitation effect with the glacier receiving a snow-fall increase over its entire area. The latter is most directly described as a change in equilibrium-line altitude (Allison and Kruss, 1977). The repeated sinusoidal fluctuations are then applied along the same axis as the initial translation, and the pseudo-sinusoidal glacier reaction is quantitatively analyzed for terminusrespone amplitude and terminus time lag. Terminusresponse amplitude is defined as half the difference between the maximum and minimum glacier lengths measured along a modeled central line. Time lag is the time elapsing between a net-balance event and the corresponding glacier reaction and is measured from applied net-balance extreme to terminus-response extreme.

\section{GLACIER DYNAMICS}

The numerical glacier model developed for this study is an extension of the deformational model of Budd and Jenssen ([1975]). It is essentially a twodimensional, short-time-step model, but a threedimensional parameterization of the continuity equation is included. The basic glacier variables which must be computed are ice velocity and depth and glacier surface elevation and extent. Velocity, depth, and surface elevation are determined at grid points spaced evenly along a longitudinal modeled line, whilst terminus position is followed between grid points. All values are re-calculated over repeated short time intervals ( 0.1 year for Lewis 
Glacier). Earlier versions of this basic model have been employed for studies of various non-surging and surging glaciers (Budd, 1975; Allison and Kruss,1977; Budd and McInnes, L'1978]). Close matching has been found between calculated and observed values of ice depth, surface velocity, and glacier extent.

For the Lewis Glacier calculations, a simplified flow scheme derived from the general model is used. Budd and Jenssen ([1975]) suggest that for ordinary glaciers the large-scale average-velocity distribution may be computed assuming deformation only with no basal slip. Reproduction of the velocity with this assumption is sufficient for this study. For nonsurging, temperate glaciers in middle and high latitudes, Budd and Jenssen ([1975]) and Smith (unpublished) employed computation schemes which includes only a deformational ice-velocity formulation. Allison and Kruss (1977) modeled the retreat of the (tropical) Carstensz Glacier also with a deformational model. The matching between computed results and observed velocity values found for a range of valley glaciers using a non-sliding velocity scheme suggests the possibility of employing such an approach for this study of Lewis Glacier, which is a slow-moving temperate glacier (maximum velocity less than $5 \mathrm{~m} \mathrm{a}^{-1}$ in 1978).

The present model, excluding the basal-sliding segment, is outlined in Table I: Table I defines one complete computation cycle in the sequence programmed, each pass through this sequence constituting one time step. The equation numbers in this table refer to equations in the text. The total surface velocity $U_{S}$ (see total velocity block of Table I) is the sum of the surface deformational velocity $V_{S}$ (Equation (2) in Table I) and the sliding velocity $V_{b}$. The deformational-velocity scheme follows from Budd and Jenssen $([1975])$. The change in ice depth $\Delta Z$ over a time step, and hence the ice depth $z$ itself, is determined from considerations of glacier net balance and internal ice re-distribution, whilst ice-surface elevation $E$ is the bedrock elevation $b$ plus the ice depth (see ice-depth block of Table I). The exact glacier length $X$ is also determined from continuity (Equations (16) to (18)). Budd and Jenssen (1975) during their modeling found the second right-hand term of Equation (4) in Table I to be very small. This also proved to be true for Lewis Glacier during some initial computations. Hence, this longitudinal stress "correction" term is not included in the computations reported here. The specific flow model employed in this study is described by the Table I equations with $\frac{\sigma_{x}^{1}}{1}$ and $V_{b}$ both set to zero.

The importance of $\sigma_{x}^{+}$in the calculation of velocity can also be estimated using an iterative approach to the solution of the set of equations (modified by a stress shape factor) involving longitudinal stress outlined in Paterson (1981, p. 89-91) (personal communication from I.M. Whillans). Solutions were obtained for the regions of mean positive and negative down-glacier velocity gradients. Setting $\sigma_{x}^{\top}$ to zero was found to be quite an acceptable approximation within the limits of ice modeling.

Regarding the surface velocity, this model was employed by Hastenrath and Kruss ([1981], 1982) in computing the velocity of Lewis Glacier since late in the nineteenth century; it was found that surface velocities could be well reproduced. Bhatt and others ([1982]) also used this model in estimating the bedrock topography beneath Lewis Glacier in 1978 from known values of the surface velocity and details of the topography. The numerical calculations gave ice depths comfortably within the error ranges of results from seismic and gravimetric analyses. Bhatt and others ([1982] and Hastenrath and Kruss ([1981], 1982) both discuss the particular suitability of this basic model to the specific situation of Lewis Glacier.

Calculation of the deformational ice velocity is of primary importance in this study. Many researchers

\section{TABLE I. THE CALCULATION ROUTINE OF} THE LEWIS GLACIER FLOW MODEL

deformational velocity

$$
\begin{array}{rlr}
\alpha & =-\frac{\partial E}{\partial x} \\
\tau_{\mathrm{c}} & =s \rho g Z \sin \alpha \\
\tau_{\mathrm{b}} & =\tau_{\mathrm{c}}-\dot{2} \frac{\partial Z \overline{\sigma_{x}^{\prime}}}{\partial x} \quad \frac{\partial Z \overline{\sigma_{x}^{\prime}}}{\partial x}=0 \\
V_{\mathrm{i}} & =k \tau_{b}^{n} Z \\
V_{\mathrm{s}} & =\frac{n+2}{n+1} V_{\mathrm{i}}
\end{array}
$$

total velocity

$$
U_{\mathrm{s}}=V_{\mathrm{s}}+\not{ }_{\mathrm{b}}{ }^{0} \quad V_{\mathrm{b}}=0
$$

ice depth

$$
\begin{aligned}
\Delta Z & =\left\{A-\frac{1}{W_{\mathrm{s}} \partial x}\left(C_{\mathrm{v}} U_{\mathrm{s}} m+1, W_{\mathrm{s}} Z\right)\right\} \Delta t \\
Z & =Z+\Delta Z \\
E & =b+Z
\end{aligned}
$$

glacier length

$$
\begin{aligned}
& M_{a(t)}= \\
& M_{\mathrm{a}(t-1)}+\left(A W_{\mathrm{s}} r+C_{\mathrm{v}} U_{\mathrm{s}} \frac{m}{m+1} W_{\mathrm{s}} Z\right) \Delta t \\
& r \quad=\frac{J+1 M_{a(t)}}{J} W_{\mathrm{s}} Z
\end{aligned}
$$

$X \quad=\left(N_{g}-1\right) \delta X+r$

\section{$A$ net balance}

$b$ bedrock elevation

$C_{\mathrm{v}} \quad$ cross-section velocity ratio $=\bar{V} / U_{\mathrm{s}}$

$E$ ice-surface elevation

$g$ gravitational acceleration

$J$ power of longitudinal snout shape

$k$ flow law constant

$m$ power of valley shape

$M_{a(t)}$ ice volume past last grid point

$n$ power of flow law

$N_{\mathrm{g}}$ number of grid points in use

$r$ distance from last grid point to terminus

$s$ stress shape factor

$\Delta t$ time step

$U_{s}$ surface velocity

$\checkmark$ cross-section mean velocity

$V_{\mathrm{b}}$ basal-sliding velocity

$V_{i}$ averaged deformational velocity (vertical average)

$V_{\mathrm{s}}$ surface deformational velocity

$W_{\mathrm{s}}$ surface width

$X$ glacier length

$\delta X$ grid point spacing

$x$ down-glacier axis or position

$Z$ ice depth on modeled line

$\alpha \quad$ ice surface slope

$\rho$ ice density

$\overline{\sigma_{x}^{\prime}} \quad$ longitudinal stress deviator

$\tau_{\mathrm{b}}$ basal shear stress

$\tau_{c} \quad$ gravitational stress 
have utilized flow laws of ice to relate velocity and shear stress. Budd (1969) discusses several flow laws applicable to differing stress ranges which involve the deformational velocity $V_{j}$ and the basal shear stress $\tau_{b}$. In this model, a straightforward power flow law is used as only a comparatively small $\tau_{b}$ range need be covered, i.e.

$$
V_{\mathrm{i}}=k \tau_{\mathrm{b}}^{n} Z
$$

where $V_{j}$ is the vertically-averaged mean deformational velocity, $Z$ is ice depth, and $k$ and $n$ are empirically-determined constants. Glen (1955) and Mellor (1959) found $n$ to be between 3 and 4 for stresses greater than one bar. For lower stresses, up to approximately 0.5 bar, Mellor and Smith (1966) suggest that $n$ is close to one. Present-day basal stresses of Lewis Glacier are of the order of one bar and less, and hence an intermediate value for $n$ is used. This value is used by Budd (1975) and is near to that of Budd and Jenssen ([1975]). However, the value of $n$ is not strictly defined for a valley glacier; if anything, $n$ may be larger than 2 . The effect on the computed retreat of Lewis Glacier of changing $n$ from 2 to 3 is explored by Kruss (in press). The values of $k$ input for Lewis Glacier are 0.16 and 0.14 bar $^{-n} a^{-1}$ for $n$ equals 2 and 3 , respectively, from a formulation for temperate ice by Budd and Jenssen ([1975]).

The surface deformational velocity $V_{S}$ is obtained from $V_{i}$ using

$$
V_{\mathrm{s}}=\frac{n+2}{n+1} V_{\mathrm{i}}
$$

which follows for a power law definition of the velocity $v_{z}$ at depth $z$ from the surface (Budd, 1969) in the expression

$$
v_{\mathrm{i}}=\frac{1}{Z}\left\{v_{\mathrm{s}} z-\int_{0}^{z}\left(v_{\mathrm{s}}-v_{z}\right) \mathrm{d} z\right\}
$$

Thus, the calculation of surface velocity is dependent on the derivation of a basal-stress solution (see Equations (1) and (2)).

The form of the $\tau_{b}$ solution is determined by the wavelength of the surface features to be modeled. For wavelengths greater than of order ten times the ice depth, Budd (1971) has suggested that

$$
\tau_{\mathrm{b}}=\tau_{\mathrm{c}}-2 \frac{\partial Z \overline{\sigma_{x}^{\prime}}}{\partial x}
$$

where $\overline{\sigma_{x}^{\prime}}$ is the vertical average of the longitudinal stress deviator and $\tau_{c}$ is the centerline down-slope stress. However, this equation may rather be representational than quantitative (cf. Nye, 1979 Hutter and others, 1981). Nye (1965[a]) found that the frictional effect of valley walls must be included when treating valley glaciers. This effect is embodied in the stress shape factor $s$ of the centerline stress equation

$$
\tau_{\mathrm{c}}=\operatorname{s\rho g} Z \sin \alpha
$$

where $\rho$ is ice density and $g$ is gravitational acceleration. The ice surface slope $\alpha$ is defined by

$$
\alpha=-\frac{\partial E}{\partial x}
$$

where $E$ is the ice-surface elevation.
The stress deviator $\overline{\sigma_{x}^{\prime}}$ is found via a

flow law applicable to a wider stress range than the power approximation (Butkovich and Landauer, 1960)

$$
\overline{\sigma_{x}^{\prime}}=\tau_{1} \sinh ^{-1}\left(\frac{1}{\varepsilon_{1}} \frac{\partial V}{\partial x}\right)
$$

where $\tau_{1}$ and $\varepsilon_{1}$ are constants of value 0.3 bar and $0.685 \mathrm{a}^{-1}$, respectively, for temperate ice (Budd and Jenssen, [1975]). $V$ is the vertical average of the total velocity, i.e.

$$
V=V_{\mathrm{i}}+V_{\mathrm{b}}
$$

where $V_{b}$ is the basal sliding velocity. The surface deformational velocity may be determined from Equations (1), (2), and (4) to (8). The computation sequence programmed is included in Table I.

The estimation of both ice depth and glacier length is dependent on mass continuity and must include mass addition at the ice surface and internal mass re-distribution due to glacier flow. If we take a volume element from bedrock to surface across the glacier

$$
\Delta z=A \Delta t+\frac{\Delta /}{\bar{W}_{\mathrm{s}} \delta x}
$$

where $\Delta z$ is the change in ice depth of the element over the time interval $\Delta t, A$ is the net balance, and $\bar{W}_{S}$ and $\delta x$ are mean width and length of the volume element, respectively. The net ice inflow $\Delta I$ is a function of the change, over $\delta x$, in crosssection mass flux, i.e.

$$
\Delta /=-\delta(V \Omega) \cdot \Delta t
$$

where $\bar{V}$ is cross-section mean velocity and $s$ is crosssectional area. In a similar way to Nye (1965[a]), $\bar{V}$ is taken proportional to the centerline velocity, i.e.

$$
\bar{V}=C_{\mathrm{v}} U_{\mathrm{s}}
$$

where $U_{S}$ is the total surface velocity and $C_{V}$, the cross-sectional velocity ratio, is dependent on valley shape. If the shape of the valley cross-section is parameterized by a simple power fit of order $m$, i.e.

$$
z \propto W_{s}^{m}
$$

where $m$ is the valley power, then

$$
\Omega=\frac{m}{m+1} W_{s} Z
$$

Combining Equations (9) through (11) and (13) for $\delta x$ small leads to

$$
\left.\frac{\Delta Z}{\Delta t}=A-\frac{1}{W_{\mathrm{s}} \partial x} \frac{\partial}{\partial C_{\mathrm{v}}} U_{\mathrm{s}} \cdot \frac{m}{m+1} W_{\mathrm{s}} Z\right)
$$

This equation is employed in the glacier-flow model for the computation of ice depth change over a time step. Thus, the ice depth $Z$ and the surface elevation $E$ are defined at any time (see ice depth block of Table I).

The parameters $C_{\vee}$ and $m$ are constant for each grid point. However, the surface width is recalculated after each time step from input values of reference ice depth and width, $Z$ ref and $W_{\text {ref }}$,
respectively. From Equation (12) 


$$
W_{\mathrm{s}}=W_{\mathrm{ref}}\left(Z_{\mathrm{ref}}\right)^{1 / m}
$$

The glacier extent is determined more accurately than the grid spacing by calculating the volume of ice past the last grid point in use, and then computing the length necessary to contain this volume within a specified longitudinal snout shape (Equations (16) to (18) of Table I). The volume of ice at the current time $t\left(M_{a}(t)\right)$ in this terminus region is the volume at the preceding time step $\left(M_{a}\left(t_{-1}\right)\right.$ plus the change over a time step resulting from net balance and ice inflow past the final grid point, i.e. in a similar way to Equation (14),

$$
M_{a(t)}=M_{a(t-1)}+\left(A W_{\mathrm{s}} r+C_{\mathrm{v}} U_{\mathrm{s}} \frac{m}{m+1} W_{\mathrm{s}} Z\right) \Delta t
$$

where $r$ is the distance from the last grid point in use to the glacier terminus. The net balance is a mean over $r$ whilst the remaining values are at the final grid point. A simple power fit of order $J$ to this snout volume and the ice depth at the last grid point gives a snout length

$$
r=\frac{J+1}{J} \frac{M_{a(t)}}{W_{s} Z}
$$

Finally, the total glacier length $X$ is the distance along the modeled line to the last grid point plus $r$, i.e.

$$
X=\left(N_{g}-1\right) \delta X+r
$$

where $N_{\mathrm{g}}$ is the number of grid points in use and $\delta X$ is the grid spacing.

Much of the data input to this model must be defined at grid points spaced $50 \mathrm{~m}$ apart for Lewis Glacier along a central, longitudinal modeled line. An important parameter is the bedrock elevation along this line. The bedrock topography is known below the 1978 terminus $(4600 \mathrm{~m})$ and at the head of the glacier $(4980 \mathrm{~m})$ as the Lewis Glacier commences on a rock slope. For grid points covering the present ice, the bedrock elevation has been determined using three distinct techniques (Bhatt and others, [1982]), a maximum ice depth in 1978 of less than $50 \mathrm{~m}$ being found.

The flow cross-sectional area and the glacier surface width at each grid point are approximated by a mathematical power-law representation of the crosssection shape, i.e. the valley power $m$ and reference width $W$ ref and depth $Z$ ref values. As cross-section profiles at grid points within the present ice were not well defined, a valley power $m$ of 2 , which was constant for the entire glacier, was used; this value was based on the value appropriate to the exposed valley walls. Definition of $m$ at a value other than unity allows for a modeling of cross-sectional area and surface-width variation with time. The reference width $W_{\text {ref }}$ and depth $Z$ ref values used correspond approximately to the surface widths and ice depths at the late nineteenth-century maximum glacier.

Neither the cross-section velocity ratio $C_{v}$ nor the stress shape factor $s$ are well known although they are discussed by Nye $(1965[\mathrm{a}])$. Hence, a model tuning process was followed for the final definition of these variables. Employing the Nye (1965[a]) information as a guide, $C_{v}$ and $s$ values were initially defined for each grid point. Model calculations were then carried out for a range of $C_{v}$ and $s$ values until the best fit to 1978 ice depths and surface velocities was found. For Lewis Glacier, $C_{V}$ values were about 0.7 and $s$ values were derived in the range 0.8-0.9.

Net balance is defined by altitude bands for Lewis Glacier rather than at each grid point, thus allowing a feedback response between net balance and changes in surface elevation. The net balance employed is that constructed for the $1978 / 79$ balance year (March to March); it exhibits maximum ablation of about $4 \mathrm{~m} \mathrm{a}^{-1}$ water equivalent near the glacier terminus and increases to a maximum accumulation rate of about $1 \mathrm{~m} \mathrm{a}^{-1}$ for the 4850-4950 m band before decreasing slowly once more at higher elevations.

\section{RESULTS}

The response of Lewis Glacier is modeled about a steady state of length $1.32 \mathrm{~km}$ which is the mean of the late-nineteenth century maximum of $1.60 \mathrm{~km}$ and the 1978 minimum of $1.04 \mathrm{~km}$ (Kruss, in press). Netbalance sinusoidal oscillation periods from 20 to 1000 years are covered, as are applied amplitudes of 0.1 to $0.5 \mathrm{~m} \mathrm{a}^{-1}$ of ice (with respect to the balance axis) and 10 to $50 \mathrm{~m}$ (with respect to the elevation axis). Figures 1 and 2 summarize the time $\mathrm{lag}$ and amplitude of the terminus response for these sinusoidal fluctuations. The plotted time lags are means over the applied net-balance amplitude range and also between the lags at the computed maximum and minimum extents, the lag behavior of the glacier at these two extremes being somewhat different.

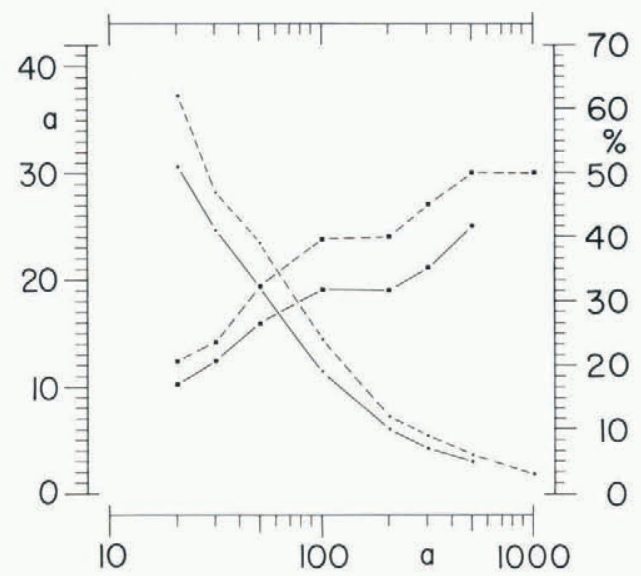

Fig. 1. Time lag between net-balance variation and Lewis Glacier terminus response. The mean time lag (ordinate) is plotted against the period of the applied sinusoidal balance oscillation (abscissa) and is expressed in years (squares, left scale) and as a percentage of the applied period (dots, right scale). Dashed and solid lines denote translation with respect to the balance and elevation axes, respectively.

The time lag between sinusoidal net balance event and glacier response (Fig. 1) exhibits a very similar pattern for translation along the balance and elevation axes, with the latter on average about $20 \% 10$ wer in magnitude. The time lag expressed in years increases from a minimum of about 10 years for an applied period of 20 years to a maximum at a 1000 year period of about 30 years. The time lag at 1000 years for elevation-axis translation is not given in Figure 1 because there are instability problems associated with the very small glacier minimum lengths obtained at this long period. Also included in Figure 1 is the time lag as a percentage of applied period. These curves show a rapid decrease from a maximum of more than $50 \%$ for a 20 year period to a minimum at 1000 years of only a few per cent. In contrast to this high dependence on applied period, time lag is virtually independent of net balance amplitude. At a given period, the average variation about the mean values given in Figure 1 (see above) is $\pm 5 \%$. 


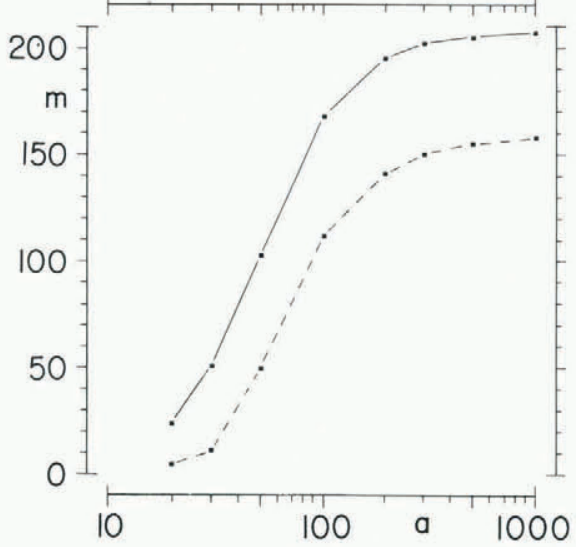

Fig. 2. Amplitude of the Lewis Glacier terminus response. The terminus response amplitude (ordinate) is plotted against the period of the applied sinusoidal balance oscillation (abscissa). A dashed line indicates a response to variation in the balance axis of amplitude $0.3 \mathrm{~m} \mathrm{a}^{-1}$ of ice. A solid line indicates a translation with respect to the elevation axis of amplitude $30 \mathrm{~m}$, which is most directly described as a $30 \mathrm{~m}$ change in equilibrium-line altitude.

The terminus-response amplitude (Fig. 2) increases rapidly with period for the higher frequencies but approaches a maximum value at periods longer than about 200 years. For the results included in Figure 2, which correspond to translations along the balance and elevation axes of $0.3 \mathrm{~m} \mathrm{a}^{-1}$ of ice and $30 \mathrm{~m}$ respectively, the terminus-response amplitude varies from about $10 \mathrm{~m}$ at a 20 year period to a maximum of more than $150 \mathrm{~m}$. Further, in contrast to time lag, the response amplitude was found to be linearly dependent on applied amplitude (coefficient of determination $R^{2}$ equals 1.0). However, a doubling of the applied net balance amplitude does not result in a two-fold increase in terminus amplitude, rather the change is by a mean factor of about 1.9 for Lewis Glacier.

It is relevant here to compare the characteristic results obtained for the present balance-axis study with similar results for other alpine glaciers. The terminus reaction of Hintereisferner, Austria, to sinusoidal net-balance oscillations in the balance axis has been computed for mean lengths of 9.7 and $7.7 \mathrm{~km}$ (Kruss, unpublished). Nye (1965[b]) estimated the frequency response of Storglaciären, Sweden, and South Cascade Glacier, U.S.A.; both glaciers have similar lengths (about $3.5 \mathrm{~km}$ ) but Storglaciären moves at only half the speed. The frequency response calculated at $8.0 \mathrm{~km}$ for Berendon Glacier, Canada, is included by Untersteiner and Nye (1968). In the Hintereisferner study, changes in the terminus extent were modeled in the same way as in the present work. For the remaining glaciers, however, the glacier length was held constant and the change in the ice depth near the glacier terminus in response to harmonic net balance fluctuations was calculated. Hence, whilst it is appropriate to compare many of the results of these studies, the Hintereisferner and Lewis Glacier response amplitudes are not compatible in terms of absolute magnitude with the amplitude results for Berendon Glacier, Storglaciären, and South Cascade Glacier.

The five glaciers all exhibit time lags of order 10 years at a 20 year period, while at the longer periods the time lags approach a maximum. At a 1000 year period, the lags for Hintereisferner, Berendon Glacier, Storglaciären, South Cascade Glacier, and Lewis Glacier are about $110,55,55,40$, and 30 years, respectively.
The curve of time lag expressed as a percentage of applied period versus this time period exhibits a peak for each glacier except Lewis Glacier. This maximum is at about $55 \%$ and 90 years for Hintereisferner, and about $45 \%, 50$ years; $45 \%, 55$ years; and $45 \%, 25$ years for Berendon Glacier, Storglaciären, and South Cascade Glacier, respectively. The Lewis Glacier maximum is evidently at a period less than or equal to 20 years (see Fig. 1) and is at least $5 \%$. At periods below this peak, the time lag asymptotically approaches a value apparently about $25 \%$ of applied period (equivalent to $90^{\circ}$ phase lag), whilst the curve tends towards zero at longer periods.

The time lag was found to be largely independent of applied net-balance amplitude over the range 0.1 to $0.5 \mathrm{~m} \mathrm{a}^{-1}$ of ice for both Lewis Glacier and Hintereisferner. This is an inherent feature of Nye's analysis (Nye, 1965[b]).

The response amplitude approaches a maximum asymptotically at the longer periods. For a period of 1000 years, the terminus amplitudes for Hintereisferner and Lewis Glacier are about 1700 and $160 \mathrm{~m}$, respectively, for an applied amplitude of $0.3 \mathrm{~m} \mathrm{a}^{-1}$ of ice. At the shorter periods the terminus response is very small, being about one metre for $0.3 \mathrm{~m} \mathrm{a}^{-1}$ of ice applied amplitude and 20 year period. A basic feature of Nye's approach is a linear dependence between the amplitude of the response near the terminus and the applied net-balance amplitude. Such a dependence was also found for the Hintereisferner and Lewis Glacier terminus responses.

It is relevant to discuss the importance in these. Lewis Glacier calculations of the parameters $c_{v}, s$, and $J$ (the cross-section velocity factor, stress shape factor, and the power of the longitudinal snout shape) which are dependent on the glacier dimensions. The terminus response of the Lewis is quite stable to changes in $C_{v}$ and $s$; there exists a stabilizing feedback between the effect on the integrated mass flux caused by varying these parameters and the opposing influences of re-adjustment in the glacier dimensions and velocity. Consider, for example, the extreme case of a steady-state glacier with net balance and surface width fixed in time. Changing $C_{\mathrm{V}}$ or $s$ will not bring about any change in terminus position in this case; rather, re-adjustment is in the velocity and depth at each point within the glacier such that the integrated net balance remains balanced by cross-section flux. A similar though less extreme argument may be applied to this response environment, where only the integrated response of the whole glacier at the terminus is being studied.

Numerical experiments support this assertion. Varying $s$ by $0.2(25 \%)$ results in less than $10 \%$ changes in both computed time lag and amplitude responses. Similarly, changing $C_{v}$ by $0.2(25 \%)$ prcduces variations in lag and length response of at most $5 \%$.

The terminus power $J$ is somewhat different as it must, in part, be set to ensure smooth growth and retreat of the ice past grid points. The parameterization of the near-terminus region embodied by Equations (16) and (17) compensates for the necessarily finite and limited number of grid points. Significant changes of $J$ from its best value will not affect the major features of the response but will result in computationally unacceptable discontinuities in terminus movement through grid points.

\section{CONCLUSIONS}

A number of characteristic features concerning the reaction at the glacier terminus to sinusoidal netbalance fluctuations of various frequencies and amplitudes are apparent. Time lag is dependent on applied net-balance period but essentially independent of applied amplitude. At periods below about 10 years 
this lag approaches a minimum of $25 \%$ of the applied period, whilst at the longer applied periods an approach to a maximum in absolute terms is found. For Lewis Glacier this maximum is about 30 years for variation in the balance axis and about 5 years less for change in equilibrium line altitude. This difference is representative of variations in time lag to be expected depending on the particular climatic forcing involved. It occurs here because the Lewis Glacier net-balance elevation profile is very steep in the ablation zone and relatively quite flat in the accumulation zone; for such curves translation parallel to the elevation axis produces net-balance change concentrated in the lower glacier.

The response amplitude is dependent on both applied period and amplitude, the dependence in the latter case being linear. For a given applied amplitude, the response amplitude is comparatively very small at the shorter periods, i.e. periods on the order of decades and less for Lewis Glacier, and approaches a maximum asymptotically for the longer periods, greater than about 200 years for Lewis Glacier.

\section{ACKNOWLEDGEMENTS}

The guidance of $\mathrm{S}$. Hastenrath in regard to this particular project and W.F. Budd, U. Radok, D. Jenssen, B.J. McInnes, and I an Whillans concerning model development is gratefully acknowledged. This work was supported by U.S. National Science Foundation grants EAR76-18881, EAR77-13130, and EAR79-23897 and by University of Wisconsin, Wisconsin Alumni Research Foundation, and Vilas Fellowships.

\section{REFERENCE:}

Allison, I.F., and Kruss, P.D. 1977. Estimation of recent climate change in Irian Jaya by numerical modeling of its tropical glaciers. Arctic and Atvine Research, Vol. 9, No. 1, p. 49-60.

Bhatt, N., and others. [1982.] Ice thickness determination at Lewis Glacier, Mount Kenya: seismology, gravimetry, dynamics, by N. Bhatt, S. Hastenrath, and P.[D.] Kruss. Zeitschrift fïr Gletscherkunde and Giazialgeologie, Bd. 16, Ht. 2, 1980, p. 213-28.

Budd, W.F. 1969. The dynamics of ice masses. ANARE Scientific Reports, Ser. A(IV). Glaciology. Publication No. 108.

Budd, W.F. 1971. Stress variations with ice flow over undulations. Jovenal of Glaciology, Vol. 10, No. 59, p. $177-95$.

Budd, W.F. 1975. A first simple model for periodically self-surging glaciers. Jownal of Glaciology, Vol. 14 , No. 70 , p. 3-21.

Budd, W.F., and Jenssen, D. [1975.] Numerical modelling of glacier systems. [Union Géodésique et Géophysique Internationale. Association Internationale des Sciences Hydrologiques. Commission des Neiges et Glaces.] Symposizm. Neiges et glaces. Actes du colloque de Moscow, août 1971, p. 257-91. (IAHS-AISH Publication No. 104.)

Budd, W.F., and McInnes, B.J. [C ${ }^{C}$ 1978.] Modelling surging glaciers and periodic surging of the Antarctic ice sheet. (In Pittock, A.B., and others, ed. Climatic change and variability: a southern perspective. Editors: A.B. Pittock, L.A. Frakes, D. Jenssen, J.A. Peterson, J.W. Zillman. Cambridge, etc., Cambridge University Press, p. 228-33.)

Butkovich, T.R., and Landauer, J.K. 1960. Creep of ice at low stresses. U.S. Snow, Ice and Permafrost Research Establishment. Research Report 72.

Caukwell, R.A., and Hastenrath, S. 1977. A new map of Lewis Glacier, Mount Kenya. Erdkunde, Bd. 31, Ht. 2, p. 85-87.

Charnley, F.E. 1959. Some observations on the glaciers of Mt. Kenya. Jorenal of Glaciology, Vol. 3, No. 26, p. 480-92.

Glen, J.W. 1955. The creep of polycrystalline ice. Proceedings of the Royal Society of London, Ser. A, Vol. 228, No. 1175 , p. 519-38.

Hastenrath, S. 1975. Glacier recession in East Africa. (In Proceedings of the WMO/IAMAP symposium on longterm climatic fluctuations, Norwich, 18-23 August 1975. Geneva, World Meteorological Organization, p. 135-42. (WMO No. 421)).

Hastenrath, S., and Caukweli, R.A. 1979. Variations of Lewis Glacier, Mount Kenya, 1974-78. Erdkunde, Bd. 33, Ht. 4, p. 292-97.

Hastenrath, S., and Kruss, P.D. [1981.] Dynamics of crevasse pattern at Lewis Glacier, Mount Kenya. Zeitschrift fïr Gletscherkunde und Glazialgeologie, Bd. 15, Ht. 2, 1979, p. 201-07.

Hastenrath, S., and Kruss, P.D. 1982. On the secular variation of ice flow velocity at Lewis Glacier, Mount Kenya, Kenya. Joronal of Glaciology, Vol.'28, No. 99, p. 333-39.

Hutter, K., and others. 1981. First-order stresses and deformations in glaciers and ice sheets, by K. Hutter, F. Legerer, and U. Spring. Jovenal of Glaciology, Vol. 27, No. 96, p. 227-70.

Kruss, P.D. In press. Climate change in East Africa: a numerical simulation from the 100 years of terminus record at Lewis Glacier, Mount Kenya. Zeitschrift fïr Gletscherkinde cond Glazialgeologie, Bd. 19, Ht. 2, 1983.

Kruss, P.D. Unpublished. Numerical modeling of climatic change from the terminus record of Lewis Glacier, Mount Kenya. [Ph.D. thesis, University of Wisconsin-Madison, 1981.]

Mellor, M. 1959. Creep tests on Antarctic glacier ice. Nature, Vol. 184, No. 4687, p. 717.

Mellor, M., and Smith, J.H. 1966. Creep of snow and ice. U.S. Cold Regions Research and Engineering Laboratory. Research Report 220.

Nye, J.F. 1965[a]. The flow of a glacier in a channel of rectangular, elliptic, or parabolic crosssection. Jownal of Glaciology, Vol. 5, No. 41, p. 661-90.

Nye, J.F. 1965[b]. The frequency response of glaciers. Jounal of Glaciology, Vol. 5, No. 41, p. 567-87.

Nye, J.F. 1969. The effect of longitudinal stress on the shear stress at the base of an ice sheet. Journal of Glaciology, Vol. 8, No. 53, p. 207-13.

Smith, I.N. Unpublished. Numerical modeling of glaciers and their response to mass balance oscillations. [B.SC. (Hon.) thesis, University of Melbourne, 1976.]

Trol1, C., and Wien, K. 1949. Der Lewisgletscher am Mount Kenya. Geografiska Annaler, Arg. 31, Ht. 1-4, p. 257-74.

Untersteiner, N., and Nye, J.F. 1968. Computations of the possible future behaviour of Berendon Glacier, Canada. Joumal of Glaciology, Vol. 7, No. 50, p. 205-13. 